\title{
Studies of Lactate Dehydrogenase of Mycoplasma mycoides var. mycoides
}

\author{
By B. A. ALLSOPP AND K. P. MATTHEWS \\ East African Veterinary Research Organization, Muguga, Kenya
}

(Received 23 September 1974; revised 5 January 1975)

\begin{abstract}
SUMMARY
Polyacrylamide gel electrophoresis and isoelectric focusing techniques have been used to compare NAD-dependent $\mathrm{L}(+)$ lactate dehydrogenases (LDH) from ten different strains of Mycoplasma mycoides var. mycoides. The enzymes were not distinguished from one another, or from normal bovine LDH I by these methods.

The kinetic behaviour of LDH from $M$. mycoides ( $\mathrm{T}_{1}$ vaccine strain) suggested that the enzyme could readily reduce pyruvate or oxidize lactate in a manner which, in vertebrates, requires two different isoenzymes.
\end{abstract}

\section{INTRODUCTION}

Much work has been carried out at this Institute (L. N. Ivins, personal communication) and elsewhere (Stone \& Razin, 1973) to improve techniques for differentiating between strains of mycoplasma of different origin, but identical serologically. The fermentative mycoplasmas utilize glucose (and glycerol) as an energy source via the glycolytic pathway (Rodwell, I967) and have an NAD-dependent $\mathrm{L}(+)$ lactate dehydrogenase (LDH, EC. I.I.I.27) as the final enzyme in this sequence (Neimark \& Lemcke, 1972; Windsor \& Boarer, 1972).

Contagious bovine pleuropneumonia (CBPP) is still a threat to the cattle industry, and any extension of our knowledge of the basic properties of Mycoplasma mycoides var. mycoides, the causative organism, is therefore of value. We studied the LDH of various strains of this organism by zymogram techniques in acrylamide gels after electrophoresis and isoelectric focusing.

\section{METHODS}

Organisms. Ten strains of $M$. mycoides were examined. The $\mathrm{T}_{1}$ avianized vaccine strain, maintained at the East African Veterinary Research Organization, was mainly used. This strain is used in many parts of Africa for the control of CBPP. Three other avianized strains were used, $T_{2}$ and $T_{3}$ of East African origin and $v_{5}$ of Australian origin. Details of these avianized strains are given by Brown, Gourlay \& MacLeod (1965). The remaining six, non-avianized strains were: Gladysdale (Australia), Dakar (West Africa), Oremit, Samburu and Archer's Post (East Africa), and $\mathrm{KH}_{3} \mathrm{~J}$ (Sudan).

All strains were grown in the medium described by Gourlay (1964) and harvested at $96 \mathrm{~h}$ by centrifuging ( $10000 \mathrm{~g}$ for $30 \mathrm{~min}$ ). The cell pellet was washed three times in 67 mM-phosphate buffer $\mathrm{pH} 7 \cdot 4$ containing I mM-2-mercaptoethanol. The organisms were suspended in the same buffer $(0.1 \mathrm{~g}$ wet $\mathrm{wt} / \mathrm{ml})$ and sonicated (Io times for $30 \mathrm{~s}$ at $0^{\circ} \mathrm{C}$ ). Cell debris was removed by centrifuging ( $12000 \mathrm{~g}$ for $20 \mathrm{~min}$ ) and the resulting cell-free extract used, either immediately or after storage at $-20^{\circ} \mathrm{C}$ for a maximum of one week. 
Assays. Protein was estimated by the method of Lowry et al. (I95I). LDH was routinely estimated by the method of Schwarz \& Bodansky (I966). For the $K_{m}$ (lactate) determination, the reagent concentrations in the assay mixture $(3 \mathrm{ml})$ were tris- $\mathrm{HCl}$ buffer $\mathrm{pH} 8.9,27 \mathrm{~mm}$; NAD, $0.43 \mathrm{~mm} ; \mathrm{L}(+)$ lactate, 0.05 to $100 \mathrm{~mm}$.

Spectrophotometry was performed on a Pye Unicam SPI800 B (Cambridge, England), using I cm light path.

Polyacrylamide gel electrophoresis (p.a.g.e.). This was performed in chemically polymerized [ammonium persulphate and $N, N, N^{\prime}, N^{\prime}$-Tetramethyl-I,2-diamino-ethane (TEMED)] slab gels (I4 $\mathrm{cm} \times \mathrm{II} \mathrm{cm} \times \mathrm{I} \cdot 5 \mathrm{~mm}$ ) which were run vertically in a Perspex apparatus devised by K. C. Humphryes* and R. Hynes (ICRF, London WC2A 3 PX; personal communication). The running gel was $7.5 \%$ polyacrylamide (acrylamide plus $N, N^{\prime}$-methylene-bis acrylamide) surmounted by a stacking gel of $5 \%$ polyacrylamide containing wells for sample application.

A high $\mathrm{pH}$ discontinuous buffer system was employed, the running gel being buffered at $\mathrm{pH} 8.8(0.37 \mathrm{M}$-tris- $\mathrm{HCl})$, the stacking gel at $\mathrm{pH} 6.8(\mathrm{O} \cdot \mathrm{I} 25 \mathrm{M}$-tris- $\mathrm{HCl})$ and the running buffer at $\mathrm{pH} 8.3(0.025 \mathrm{M}$-tris- $\mathrm{HCl})$. The running buffer was circulated between the upper (cathode) and lower (anode) buffer compartments during electrophoresis to prevent electrolytic $\mathrm{pH}$ changes.

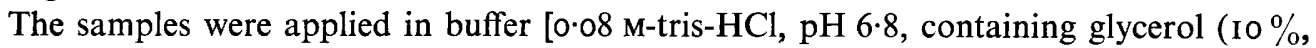
$\mathrm{v} / \mathrm{v})$ to facilitate layering, dithiothreitol $(\mathrm{O} \cdot \mathrm{I} \mathrm{M})$ to preserve enzyme activity during the run, and bromophenol blue $(2 \mu \mathrm{g} / \mathrm{ml})$ to mark the front] in an amount corresponding to 0.05 i.u. $\mathrm{LDH}$. Gels were cooled to $4{ }^{\circ} \mathrm{C}$ during the run, which was at 40 to $50 \mathrm{~V} / \mathrm{cm}, \mathrm{I} 20$ to $130 \mathrm{~mA}$, front migration being at about $3 \mathrm{~cm} / \mathrm{h}$. The run was stopped when the front was $\mathrm{I} \mathrm{mm}$ from the end of the gel. At this stage no LDH had migrated more than half the distance travelled by the front, so the latter is not shown in Fig. I.

Isoelectric focusing (i.e.f.). This was performed in photometrically polymerized slab gels $(25 \mathrm{~cm} \times$ I I cm $\times 2 \mathrm{~mm}$ ) which were $4.85 \%$ polyacrylamide containing I \% LKB (LKB Produkter, Bromma, Sweden) carrier Ampholytes pH 3.5 to Io and I $2.5 \%$ sucrose. Preparation was otherwise as described by Humphryes (1970). The gels were run horizontally in an LKB Multiphor electrophoresis apparatus.

Samples were applied to the surface of the gel, midway between the electrodes (this was important, see below), in distilled water in an amount corresponding to 0.5 i.u. of LDH. The anode and cathode solutions were I M-phosphoric acid and I M-sodium hydroxide respectively. Gels were cooled to $4{ }^{\circ} \mathrm{C}$ during the run, which was for about $2 \cdot 5 \mathrm{~h}$. The voltage applied was increased stepwise during the first hour from $200 \mathrm{~V}$ to a final value of $1000 \mathrm{~V}$. The $\mathrm{pH}$ gradients were measured on the surface of the gel using a Pye Unicam type 403-30 combined electrode.

Staining of gels for enzyme. Gels were stained by overlaying with a I \% agar solution (poured at $50^{\circ} \mathrm{C}$ ) and incubated at $37^{\circ} \mathrm{C}$ for $\mathrm{I}$ to $2 \mathrm{~h}$. The solution was buffered at $\mathrm{pH} 8.0$ $\left(0.2 \mathrm{M}\right.$-tris-HCl) and contained $0.0 \mathrm{I} \mathrm{M}-\mathrm{MgCl}_{2}, 0.19 \mathrm{M}$-sodium DL-lactate, $0.58 \mathrm{mg}$ nitro blue tetrazolium $/ \mathrm{ml}, 0.27 \mathrm{mg}$ phenazine methosulphate $/ \mathrm{ml}$, and $\mathrm{I} \cdot 9 \mathrm{mg} \mathrm{NAD} / \mathrm{ml}$. Minimum enzyme quantities detected by this system were 0.05 and 0.5 i.u. of LDH for p.a.g.e. and i.e.f. respectively.

Better definition was obtained on i.e.f. gels by soaking the gel, after the run and before pouring the agar, in an aqueous solution of $12 \mathrm{mg} \mathrm{NAD} / \mathrm{ml}$. This was decanted before pouring the agar solution, from which NAD was omitted. This procedure did not improve resolution on p.a.g.e. gels.

LDH samples from non-mycoplasmal sources. For comparison purposes, lactate dehydro- 
genases were prepared from bovine sources; these were normal bovine lymph node cells, and a culture of bovine spleen cells infected with Theileria parva (designated C2; see Malmquist, Nyindo \& Brown, 1970). Cell-free extracts were prepared from washed cells using the same technique as was applied to mycoplasma cells. Commercial samples (Sigma) of LDH I $\left(\mathrm{H}_{4}\right)$ from beef heart and pig heart and $\mathrm{LDH} 5\left(\mathrm{M}_{4}\right)$ from rabbit muscle were also used.

\section{RESULTS AND DISCUSSION}

LDH from strain $\mathrm{T}_{1}$ displayed a broad plateau of maximal activity in the $\mathrm{pH}$ range 5.2 to $7 \cdot 2$, so that assays conducted at $\mathrm{pH} 6 \cdot 7\left(25^{\circ} \mathrm{C}\right)$ by the method of Schwarz \& Bodansky (1966) were suitable. Mycoplasma mycoides contains a soluble NADH oxidase (Rodwell, 1967) for which allowance was made by initiating LDH assays with substrate. The oxidase activity amounted to IO $\pm \mathrm{I} \%$ of the LDH activity for fresh preparations under the assay conditions used, and no attempt was made to control it.

Quantitative yields of $\mathrm{LDH}$ were about $5 \times 10^{-9} \mathrm{i}$.u./cell for the $\mathrm{T}_{1}$ vaccine strain, a value higher than that $\left(4^{\cdot} \mathrm{I} \times 10^{-10}\right.$ i.u./cell) obtained by Windsor \& Boarer (1972). However, their work was confined to cultures up to $72 \mathrm{~h}$. We found that LDH increased up to $96 \mathrm{~h}$, although cell numbers were almost constant after $72 \mathrm{~h}$. After $96 \mathrm{~h}$, rapid decreases in both cell counts and LDH yields occurred. For this reason we used $96 \mathrm{~h}$ cultures for all preparations. All the strains gave similar yields of $\mathrm{LDH}$, except Gladysdale and Dakar, which yielded up to twice the amount given by the others.

On p.a.g.e. gels the LDH from all ten strains showed identical mobility (Fig. I a). This ruled out the possibility of differentiating strains by this method. Minor faint lines were seen with some samples, but these were not reproducible.

Figure $\mathrm{I} b$ shows a comparison on p.a.g.e. of $\mathrm{T}_{1} \mathrm{LDH}$ with $\mathrm{LDH}$ from bovine sources. The bovine cells show the classical pattern of LDH I to 5. The mobility of the mycoplasmal LDH is identical with that of bovine LDH I. This result is further demonstrated in Fig. I $c$, which includes bovine and porcine LDH I.

On i.e.f. gels the lactate dehydrogenases of all ten strains fell mainly at $\mathrm{pH} 4.8$ and 5.9 ; although there was activity between these values there was none outside this region. A typical pattern is seen in Fig. 2 for $\mathrm{T}_{1} \mathrm{LDH}$. There was less reproducibility between different preparations from the same strain than in the case of p.a.g.e. On some occasions only the $\mathrm{pH} 4 \cdot 8$ activity was seen, whereas on other occasions activity was almost uniform over the $\mathrm{pH}$ range 4.8 to 5.9 . These variations, however, could not be related to strain differences, and other causes were not investigated.

These results are not an artefact of the i.e.f. method; provided that the samples were applied to the gel at the mid-point, the patterns obtained with commercial LDH preparations were reproducible. The similarity between bovine LDH I and mycoplasmal LDH (Fig. 2) is just as marked on i.e.f. as on p.a.g.e. The rabbit LDH consists of five closely related isoenzymes; however these were not in any way similar to the normal LDH I to 5 isoenzymes, since the rabbit preparation appeared to be homogeneous on p.a.g.e. and its mobility coincided with that of bovine LDH 5 .

Because of the apparent similarity between bovine LDH I and mycoplasmal LDH, the kinetic behaviour of the latter was investigated. Activities were measured at various substrate concentrations for both pyruvate reduction and lactate oxidation, and $K_{m}$ values were found by performing reciprocal plots. Pyruvate reduction was measured at 37,25 and $10^{\circ}{ }_{1}^{\circ} \mathrm{C}$, lactate oxidation at $25^{\circ} \mathrm{C}$ only. In addition, the effect of added lactate on pyruvate reduction at $25^{\circ} \mathrm{C}$ was investigated. 
Origin $\rightarrow$

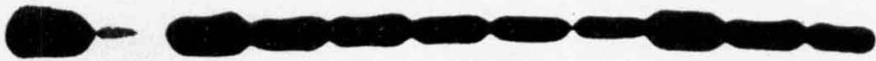

(a)

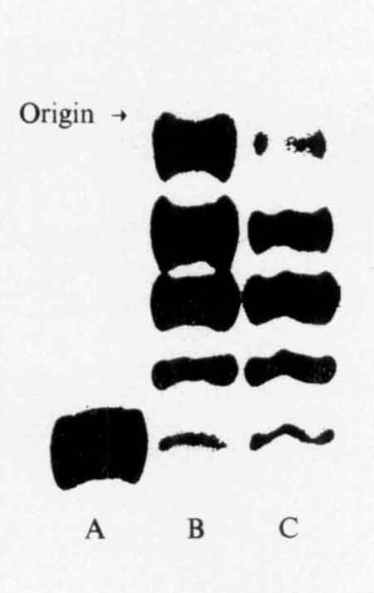

(b)
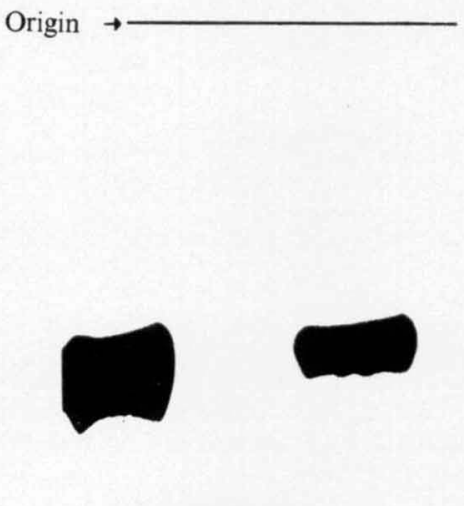

A
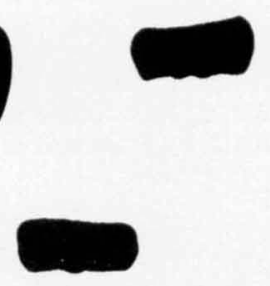

B

(c)

Fig. I. Zymograms after p.a.g.e. of various lactate dehydrogenases. For details, see Methods. (a) Zymogram after p.a.g.e. of LDH from ten strains of $M$. mycoides. The strains from left to right are: Archer's Post, Gladysdale, $T_{1}$ (East African Vaccine Strain), $T_{2}$, Dakar, Samburu, Oremit, $v_{5}$ (Australian Vaccine Strain), $\mathrm{T}_{3}$, Archer's Post, and $\mathrm{KH}_{3} \mathrm{~J}$. (b) Zymogram after p.a.g.e. of bovine and $M$. mycoides $\mathrm{LDH}$. A, M. mycoides ( $\mathrm{T}_{1}$ strain); B, bovine $\mathrm{C}_{2}$ (Malmquist et al. $\mathrm{I} 970$ ); $\mathrm{C}$, bovine lymph node. (c) Zymogram after p.a.g.e. of $M$. mycoides $\mathrm{LDH}$, porcine and bovine LDH $\mathbf{I}$. A, M. mycoides ( $\mathrm{T}_{1}$ strain) $\mathrm{LDH} ; \mathrm{B}$, porcine $\mathrm{LDH}$ I (commercial preparation); C, bovine LDH I (commercial preparation).

Figure 3 shows the variation of pyruvate reduction activity with substrate concentration. The wide plateau of high activity of $\mathrm{T}_{1} \mathrm{LDH}$ at $37^{\circ} \mathrm{C}$ is typical of the behaviour of LDH 5 $\left(\mathrm{M}_{4}\right)$ of rabbit origin (Plagemann, Gregory \& Wroblewski, 196I) and of chicken origin (Kaplan, Everse \& Admiraal, 1968). The decrease of this tolerance of high substrate levels with decrease in temperature is also evident in Fig. 3, and is normal for LDH 5 (Vesell, 1965).

The behaviour of $\mathrm{T}_{1} \mathrm{LDH}$ in lactate oxidation also showed similarities to vertebrate (rabbit) LDH 5 (Stambaugh \& Post, I966). There was a plateau from to to $50 \mathrm{~mm} \mathrm{~L}(+)$ lactate, with inhibition at higher levels. Rabbit $\mathrm{LDH}_{5}$, however, shows a maximal activity at $\mathrm{I} 50 \mathrm{mM}$ $\mathrm{L}(+)$ lactate. Rabbit LDH I $\left(\mathrm{H}_{4}\right)$, which is maximally active with a lower lactate concentra- 


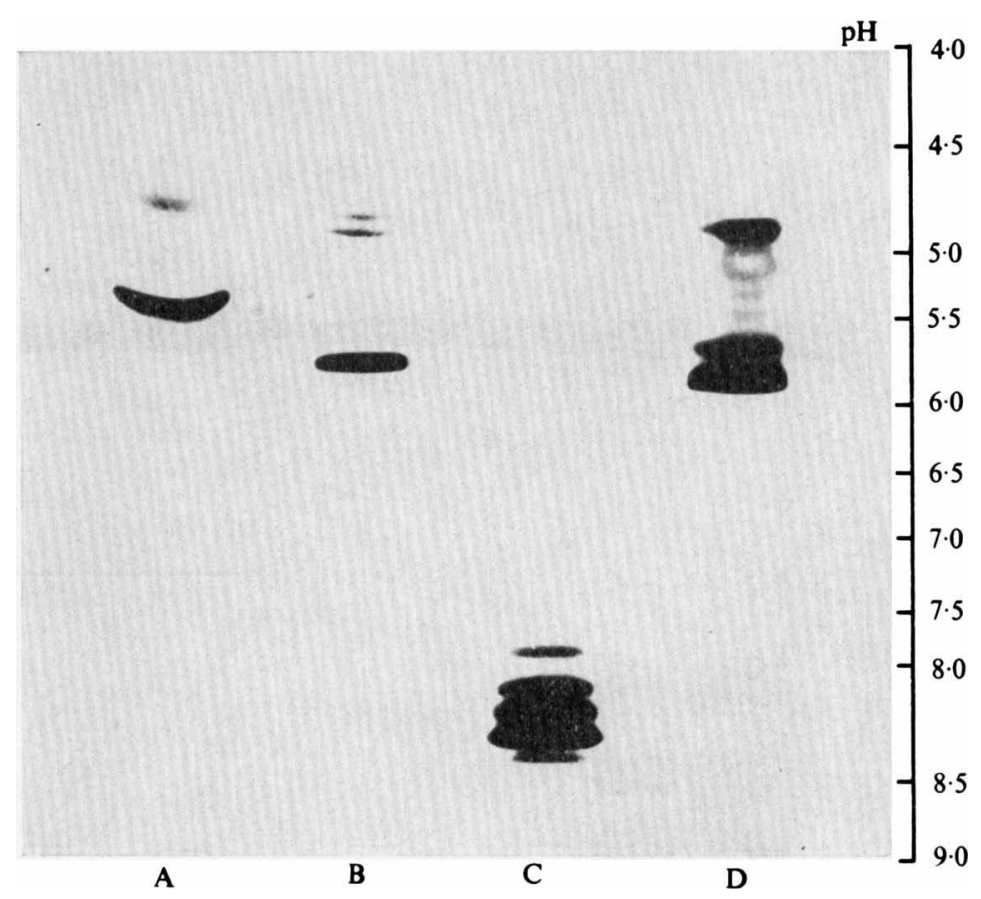

Fig. 2. Zymogram after i.e.f. of M.mycoides LDH and mammalian LDH. For details, see Methods. A, Porcine LDH I (commercial preparation); B, bovine LDH I (commercial preparation); C, rabbit LDH 5 (commercial preparation); D, M. mycoides ( $\mathrm{T}_{\mathbf{1}}$ strain) LDH.

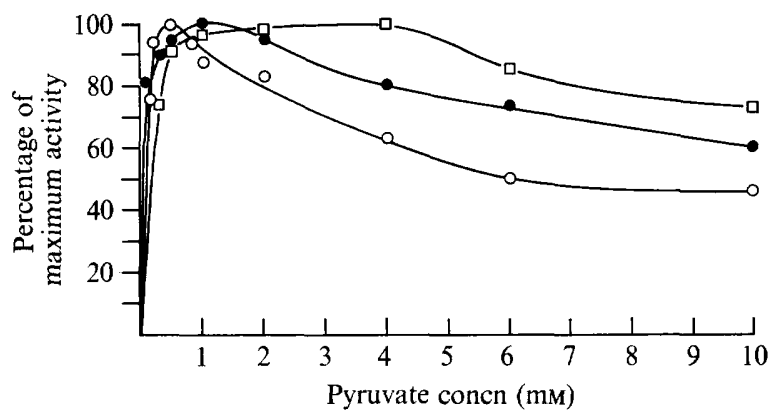

Fig. 3. Effect of substrate concentration and temperature on pyruvate reduction by $M$. mycoides $\left(\mathrm{T}_{1}\right)$ LDH. LDH assays were by the method of Schwarz \& Bodansky (1966) using pyruvate concentrations from 0.1 to $10.0 \mathrm{~mm}$. Pyruvate reduction was measured at $(\square) 37{ }^{\circ} \mathrm{C},(0) 25{ }^{\circ} \mathrm{C}$ and (O) $10^{\circ} \mathrm{C}$. Maximum $\mathrm{LDH}$ activity at these temperatures was $88.5,48 \cdot 0$ and $17 \cdot 8 \mathrm{i} . \mathrm{u}$. $\mathrm{LDH} / \mathrm{ml}$ sample, respectively.

tion ( $25 \mathrm{mM}$ ) than its corresponding LDH 5 , is much more rapidly inhibited by higher concentrations of substrate than either $T_{1} \mathrm{LDH}$ or rabbit LDH 5. Thus $\mathrm{T}_{1} \mathrm{LDH}$ shows a pattern of activity which suggests that it will more readily catalyse lactate oxidation than either vertebrate LDH I or 5 . This suggestion is confirmed by the $K_{m}$ values for $\mathrm{T}_{1} \mathrm{LDH}$, shown in Table I together with comparative figures for chicken and bovine LDHs (Pesce et al. 1967). The values show reactivity for pyruvate reduction similar to that of chicken LDH I, and much greater than that of bovine LDH I. The reactivity for lactate oxidation is high, with a 
Table I. $K_{m}$ values for various lactate dehydrogenases at $25^{\circ} \mathrm{C}$

\section{Enzyme}

Chicken $\mathrm{M}_{4}\left(\mathrm{LDH}_{5}\right)$

Bovine $\mathrm{M}_{4}(\mathrm{LDH} 5)$

Chicken $\mathrm{H}_{4}(\mathrm{LDH} \mathrm{I})$

Bovine $\mathrm{H}_{4}$ (LDH I)

M. mycoides $\mathrm{T}_{1} \mathrm{LDH}$

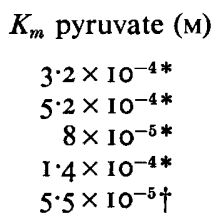

$K_{m}$ lactate (M)

$4 \times 10^{-2 *}$

$2.5 \times 10^{-2 *}$

$7 \times 10^{-3 *}$

$9 \times 10^{-3 *}$

$9 \cdot 8 \times 10^{-4} \ddagger$

* Values from Pesce et al. (1967).

$\dagger$ Assay by the method of Schwarz \& Bodansky (1966). Pyruvate concentrations 0.I to I0 mM.

$\ddagger$ Reagent concentrations in the assay mixture $(3 \mathrm{ml})$ were: tris- $\mathrm{HCl} \mathrm{pH} 8.9,27 \mathrm{~mm} ; \mathrm{NAD}, 0.43 \mathrm{~mm}$; $\mathrm{L}(+)$ lactate, 0.05 to $100 \mathrm{mM}$.

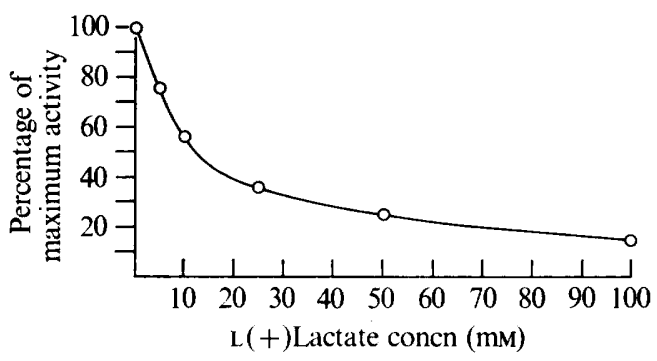

Fig. 4. Effect of lactate concentration on pyruvate reduction by $M$. mycoides $\left(\mathrm{T}_{1}\right) \mathrm{LDH}$. LDH assays were by the method of Schwarz \& Bodansky (I966) using pyruvate concentrations of 0.33 , 0.67 and $\mathrm{I} .00 \mathrm{mM}$. $\mathrm{L}(+)$ Lactate concentrations were 0 to $100 \mathrm{mM}$. The curve shown is for $0.67 \mathrm{~mm}$ pyruvate at $25^{\circ} \mathrm{C}$; differences with the other pyruvate concentrations were small.

$K_{m}$ (lactate) one-tenth of that for either chicken or bovine LDH I. This readiness of $\mathrm{T}_{1}$ LDH to catalyse lactate oxidation is further demonstrated by the inhibition by lactate of pyruvate reduction (Fig. 4). This inhibition is similar to that demonstrated with rabbit LDH I (Stambaugh \& Post, 1966).

The kinetic behaviour of $T_{1} L D H$ seems to be that of a versatile enzyme capable of performing functions which, in vertebrates, are performed by the two basic isoenzymes LDH I and 5 , and their three hybrid derivatives.

An outstanding feature of CBPP is the extremely rapid course of lung tissue destruction. It is suggested that the ability of $M$. mycoides to multiply very rapidly in the lung tisue is made possible by the versatility of its $\mathrm{LDH}$, which enables it to utilize lactate as an energy source under aerobic conditions.

No explanation can be offered for the close duplication by $M$. mycoides LDH of the electrophoretic properties of bovine LDH I. Purification of the mycoplasmal enzyme will be necessary before it can be decided whether it is chemically similar to the bovine enzyme. Should it be so, it would not be the only bovine material which $M$. mycoides can duplicate, since the organism produces a polysaccharide, galactan, which has not been distinguished from similar material found in normal bovine lung tissue (Buttery \& Plackett, 1960).

K.P.M. was on O.D.A. secondment from M.A.F.F., V.I.C., Penrith, Cumberland (O.D.A. research project $\mathrm{R} 2844$ ). We gratefully acknowledge the technical assistance of W. O'Tumba and S. Thuku. We also thank the Director of the East African Veterinary Research Organisation for permission to publish this paper. 


\section{REFERENCES}

Brown, R. D., GourLaY, R. N. \& MACLEOD, A. K. (1965). The production of $\mathrm{T}_{1}$ broth culture contagious pleuropneumonia vaccine. Bulletin of Epizootic Diseases of Africa 13, 149-155.

Buttery, S. H. \& PlacketT, P. (I960). A specific polysaccharide from Mycoplasma mycoides. Journal of General Microbiology 23, 357-368.

GouRLAY, R. N. (1964). Antigenicity of Mycoplasma mycoides. I. Examination of body fluids from cases of contagious bovine pleuropneumonia. Research in Veterinary Science 5, 473-482.

HUMPHRYes, K. C. (1970). Isoelectric focusing of $T$. brucei subgroup antigens in thin layer polyacrylamide gel: a method for resolving and characterizing protein-carbohydrate complexes with enzymic and immunological nature. Journal of Chromatography 49, 503-510.

KaPlan, N. O., EVERSE, J. \& AdmiraAl, J. (I968). Significance of substrate inhibition of dehydrogenases. Annals of the New York Academy of Sciences 151, 400-4I2.

Lowry, O. H., Rosebrough, N. J., FarR, A. L. \& Randall, R. J. (I95I). Protein measurement with the Folin phenol reagent. Journal of Biological Chemistry 193, 265-275.

MalmQuist, W. A., NYINDo, M. B. A. \& Brown, C. G. D. (1970). East Coast fever: cultivation in vitro of bovine spleen cell lines infected and transformed by Theileria parva. Tropical Animal Health and Production 2, 139-145.

NeimarK, H. \& LemcKe, R. M. (1972). Occurrence and properties of lactic dehydrogenases of fermentative mycoplasmas. Journal of Bacteriology III, 633-640.

Pesce, A., Fondy, T. P., Stolzendach, F., Castillo, F. \& Kaplan, N. O. (1967). The comparative enzymology of lactic dehydrogenases. III. Properties of the $\mathrm{H}_{4}$ and $\mathrm{M}_{4}$ enzymes from a number of vertebrates. Journal of Biological Chemistry 242, 2 I 5 I-2167.

Plagemann, P. G. W., Gregory, K. F. \& Wroblewski, F. (I96I). Biochemische Zeitschrift 334, 37. Cited in Vesell, E. S. (1968). Multiple molecular forms of enzymes: introduction. Annals of the New York Academy of Sciences 15I, 5-13.

RoDwell, A. W. (1967). The nutrition and metabolism of mycoplasma: progress and problems. Annals of the New York Academy of Sciences 143, 88-109.

Schwarz, M. K. \& Bodansky, O. (1966). Lactic dehydrogenase (clinical aspects). In Methods in Enzymology, vol. 9, pp. 294-302. Edited by S. P. Colowick and N. O. Kaplan. London and New York: Academic Press.

Stambaugh, R. \& Post, D. (1966). Substrate and product inhibition of rabbit muscle lactic dehydrogenase heart $\left(\mathrm{H}_{4}\right)$ and muscle $\left(\mathrm{M}_{4}\right)$ isozymes. Journal of Biological Chemistry 24I, I462-1467.

Stone, S. S. \& RAZIN, S. (I973). Immunoelectrophoretic analysis of Mycoplasma mycoides var. mycoides. Infection and Immunity $7,922-930$.

VESELL, E. S. (1965). Lactate dehydrogenase isozymes: substrate inhibition in various human tissues. Science, New York 150, 1590-1593.

WINDSOR, R. S. \& BOARER, C. D. H. (1972). A method for the rapid enumeration of Mycoplasma species growing in broth culture. Journal of Applied Bacteriology 35, 37-42. 